\title{
Urgences
}

\section{On aurait dit de la couleur...}

\section{Serge Mongrain}

Numéro 27, mars 1990

Images imaginaires

URI : https://id.erudit.org/iderudit/025569ar

DOI : https://doi.org/10.7202/025569ar

Aller au sommaire du numéro

Éditeur(s)

Urgences

ISSN

0226-9554 (imprimé)

1927-3924 (numérique)

Découvrir la revue

Citer ce document

Mongrain, S. (1990). On aurait dit de la couleur... Urgences, (27), 28-30.

https://doi.org/10.7202/025569ar d'utilisation que vous pouvez consulter en ligne.

https://apropos.erudit.org/fr/usagers/politique-dutilisation/ 


\section{On aurait dit de la couleur... Serge Mongrain}

\section{PHOTO 1}

On aurait dit de la couleur un soi-disant jaune recouvert de taches et de malformations On aurait dit que l'ailleurs c'était ca le jaunissement de la mer et rien d'autre rien d'autre que ça un moment de vitesse qui s'efface 


\section{PHOTO 2}

Ici le regard n'est plus le même car le temps a déshabillé la fille il lui manque

le coin gauche de la cuisse droite ce qui devrait nous en dire suffisamment sur l'état mental du photographe et de la photographiée 
30

\section{PHOTO 3}

Elle disait que le vent devait suffire à tout

Un coin du tirage est arraché

et la fille va horizontalement jusqu'au plafond 